IZA DP No. 9049

Overeducation:

A Disease of the School-to-Work Transition System

Floro Ernesto Caroleo

Francesco Pastore

May 2015 


\title{
Overeducation: A Disease of the School-to-Work Transition System
}

\author{
Floro Ernesto Caroleo \\ University of Naples "Parthenope" \\ and IZA \\ Francesco Pastore \\ Seconda Università di Napoli \\ and IZA
}

Discussion Paper No. 9049

May 2015

IZA
P.O. Box 7240
53072 Bonn
Germany

Phone: +49-228-3894-0

Fax: +49-228-3894-180

E-mail: iza@iza.org

Any opinions expressed here are those of the author(s) and not those of IZA. Research published in this series may include views on policy, but the institute itself takes no institutional policy positions. The IZA research network is committed to the IZA Guiding Principles of Research Integrity.

The Institute for the Study of Labor (IZA) in Bonn is a local and virtual international research center and a place of communication between science, politics and business. IZA is an independent nonprofit organization supported by Deutsche Post Foundation. The center is associated with the University of Bonn and offers a stimulating research environment through its international network, workshops and conferences, data service, project support, research visits and doctoral program. IZA engages in (i) original and internationally competitive research in all fields of labor economics, (ii) development of policy concepts, and (iii) dissemination of research results and concepts to the interested public.

IZA Discussion Papers often represent preliminary work and are circulated to encourage discussion. Citation of such a paper should account for its provisional character. A revised version may be available directly from the author. 


\section{ABSTRACT}

\section{Overeducation: A Disease of the School-to-Work Transition System *}

This paper aims to survey the theoretical and empirical literature on cross-country differences in overeducation. While technological change and globalization have entailed a skill-bias in the evolution of labour demand in the Anglo-Saxon countries, instead, in other advanced economies in Western Europe the increased educational level has not been associated with a parallel raise in the share of skilled occupations, therefore generating skills mismatch. This suggests that a demand-side explanation of overeducation is justified in Western Europe, which would be also confirmed by circumstantial evidence coming from the recent literature. Nonetheless, overeducation may also turn to be positive in the long run if the expansion of the supply of skills generates a technological upgrading of the production system. Moreover, from a micro-economic point of view, recent theoretical and empirical studies tend to justify a human capital theory based interpretation of the phenomenon, whereas the disorganization of the educational system, its degree of integration with the labour market may play an important role in helping young graduates develop the work experience and the competences they need to prevent them from experiencing overeducation. Overeducation causes a penalty to individuals in terms of earnings and employment opportunities and a waste of resources to the society at large in terms of state investment into education that do not bear its yields. Both penalties are higher not only where the demand for skill is lower, but also where schoolto-work transition systems fail to effectively address the aim of generating competences rather than only education for their graduates.

JEL Classification: $\quad \mathrm{C} 25, \mathrm{C} 26, \mathrm{C} 33, \mathrm{I} 2, \mathrm{J13}, \mathrm{J} 24$

Keywords: school-to-work transition, university graduates, AlmaLaurea, overeducation, overskilling, earnings, (ordered) probit, sample selection bias, Heckit, Italy

Corresponding author:

Francesco Pastore

Department of Law

Seconda Università di Napoli

Palazzo Melzi, Piazza Matteotti

I-81055, Santa Maria Capua Vetere (Caserta)

Italy

E-mail: francesco.pastore@unina2.it

\footnotetext{
* Previous versions of this paper have been presented at: AlmaLaurea Conference, University of Bologna (11 ${ }^{\text {th }}$ of March 2011), IAB of Nuremberg $\left(26^{\text {th }}\right.$ of May 2011), XXVI AIEL Conference, Catholic University of Milan (15 ${ }^{\text {th }}$ of September 2011), University of Naples "Parthenope" $\left(30^{\text {th }}\right.$ of September 2011), University of Naples "Federico II" (26 th of October 2011), Second University of Naples $\left(22^{\text {nd }}\right.$ of December 2011), XXVII AIEL Conference (27-28 ${ }^{\text {th }}$ of September 2012), University of Pescara (2012); University of Salerno (2013). We thank all seminar participants. We are also grateful to Lilia Costabile, Giuseppe Croce, Hans Dietrich, Francesco Ferrante, Claudio Lucifora, Nadia Netti, Patrizia Ordine, Marco Pecoraro, Claudia Pigini, Giuseppe Rose, Dario Sciulli, Francesca Sgobbi, Peter Sloane and an anonymous referee for valuable comments. This notwithstanding, the authors are solely responsible for the opinions expressed in this paper.
} 


\section{Introduction}

The mismatch between the educational level of workers and that required by the jobs available in the labour market represents one of the most debated dimensions of the educational and skill mismatch. Both the horizontal and vertical dimensions of the mismatch are expected to increase in the near future. First, many observers believe that the horizontal mismatch, which happens when the level of schooling is appropriate, but the type of schooling is not (Sloane, 2003), is bound to increase due to two main factors: a) the mounting complexity of the industrial structure, which causes, indeed, a mismatch between the composition of labour demand and supply by educational types and skills; b) and the insufficient coordination of educational institutions with labour market evolutions (see, among others, Robst, 2007; and Nordin, Perrson and Rooth, 2010).

Moreover, the increasing educational level of the youngest generation causes growing concern that the mismatch will take the form of (vertical) overeducation, which happens when the years of schooling required for the job is lower than the years of schooling completed (socalled excess schooling), and overskilling, which happens when the skills required to do the job are lower than the skills individuals have.

Overeducation causes a penalty to individuals in terms of earnings and employment opportunities and a waste of resources to the society at large in terms of state investment into education that do not bear its yields (Groot 1996, Büchel et al., 2003, McGuinness, 2006).

In this paper we discuss the factors determining overeducation by reviewing the main empirical and theoretical literature. A copious research production stresses such supply side aspects as the labour market segmentation, individual characteristics, the efficiency/inefficiency of the institutions governing the school to work transitions as well as the quality of the education system. Fewer studies highlight the qualitative and quantitative demand factors and in particular the effect on the evolution of labour demand due to technological change and globalization.

Comparative evidence suggests that Italy has, like the other Mediterranean countries, a higher than average share of overeducated workers. Slightly different is the case of overskilling for which Italy tends to the European average (McGuinness and Sloane, 2010; Barone and Ortiz 2011).

In the second part of the paper we deal with the Italian specificity. We review the empirical literature with a special focus on the estimates of the wage penalty associated with overeducation. 
The outline of this paper is as follows. Section one discusses the role of the evolution of the aggregate supply of and demand for skills over time and across countries and regions. Section two provides a summary of the theoretical explanations of the emergence of the skill and educational mismatch. Section three summarizes the relevant empirical literature. Section four focuses especially on the Italian literature. Section five discusses some recent estimates of the wage penalty associated to overeducation as based on the AlmaLaurea data bank. The concluding section also discusses possible policy suggestions to reduce the impact of overeducation.

\section{The demand for and the supply of skills}

Most research focuses on the supply side and on individual factors, most probably because overeducation is typically studied based on individual level data and, in particular, on data drawn from labor force surveys. Fewer recent studies attempt to bring in the picture the demand side, which is clearly an important component of theoretical explanations since any mismatch in the level of educational qualifications and skills must be a matter of relative demand and supply of skills. Three approaches have been followed:

a) cross-country analysis;

b) comparison of local labor markets;

c) employers heterogeneity.

Cross-country analyses attempt to catch the role of the demand for skills by looking at the different characteristics of the production structure of different countries. The early literature in the field has focused on the question why the skill premium has been escalating in the USA, but not in Europe. Manacorda and Petrongolo (2000) suggest that the explanation to the above question has to be found in the different evolution of industrial development in Europe, which has been lagging behind in terms of, for instance, the ICT revolution, especially the SouthEuropean countries.

In their cross-country analysis of the determinants of the skill mismatch, Verhaest and van der Velden (2010) find that the cross-country variation in overeducation and its persistence are related, among others, to differences in the structural imbalance between the overall demand for and supply of skilled workers. Ghignoni and Verashchagina (2013) also find evidence of demand-side factors in explaining the overeducation phenomenon in a sample of $10 \mathrm{EU}$ countries.

Croce and Ghignoni (2012) find that the continuous increase in the supply of skills cannot be taken to explain the rise in overeducation but in the short run and over slowdowns of the 
business cycle. They argue that when the business cycle revert to growth, the increased supply of skills is re-absorbed. This would be in line with Acemoglu's (2002) theory of the endogeneity of technical change. In other words, overeducation would be a short-time phenomenon and a consequence of the time that is necessary for labor demand to adapt to the increased supply of skills. Schivardi and Torrini (2011) provide circumstantial evidence of the role of human capital in favoring industrial restructuring at a firm level and innovative activities.

Galasi (2008) applies the sample selection bias test to assess the role of the human capital model and the Mincerian approach versus the job competition approach to explain overeducation in a number of European countries ${ }^{1}$. He assumes that where OLS produces unbiased estimates, the human capital model would apply to overeducation, which would result from an inefficient investment in education by the individual. Instead, if wages need to be corrected for sample selection bias, then the job competition model would apply, suggesting that the demand for skills is inherently low for the production of skills that the educational system generates. He finds that the job competition model holds true for most countries in his sample, which would bring support to a demand side explanation of overeducation in most European countries $^{2}$.

Another approach has consisted of comparing local labor markets in search for the impact on the educational and skill mismatch of the industrial structure and organization. In this stream of the literature, Cainarca and Sgobbi (2009) find evidence of a strong impact of an economic structure based on traditional and scarcely innovative manufacturing activities on the probability to experience the educational mismatch in both forms of undereducation of low qualified, but highly experienced workers and overeducation of highly qualified, but unexperienced workers. Other contributions (see, for instance, Leoni 2011) focus on the role of work organization to explain the mismatch between competences acquired and tasks deployed in the firm.

\section{Theoretical explanations of overeducation}

Theories that explain overeducation range between two opposite theoretical constructs: the human capital theory and the job competition model (see, for in depth surveys, Sloane 2003, McGuinnes 2006, Leuven and Oosterbeek 2011). Traditionally, overeducation has been considered an exception to the human capital theory as it is associated to a mismatch and

\footnotetext{
${ }^{1}$ Next section provides a discussion of the different theories of overeducation at an individual level and of the underlying hypothesis regarding the equilibrium level of the market for skills.

${ }^{2}$ For a slightly different interpretation of the sample selection bias test, see later in this essay and see also Caroleo and Pastore (2013).
} 
therefore a market disequilibrium. Accordingly, it should be a short term phenomenon as a sufficient degree of wage flexibility should restore any imbalance between supply and demand in the graduate labour market unless some persistent, often unobserved, low ability / skill problem affects the permanently overeducated. As Leuven and Oosterbeek (2011) note, more recent literature tends to restore the validity of the human capital theory in explaining overeducation.

To clarify this line of reasoning, consider that, as a matter of fact, overeducation could be conceived as a signal of a lack of the work-related component, rather than a waste of human capital. Recall from the Nobel prize winner, Gary Becker (1964), that human capital is not only represented by the level of education but also by generic work experience and the work experience that is specifically acquired by working for a sufficiently long period of time on a particular type of job. Overeducation is therefore a consequence of a lack of skills that could be acquired through work experience and this is typical of young people, despite their increasing educational level. One would expect hence that overeducation be more common where the educational system is of a sequential type, namely where the mission of the educational system is generating general education rather than all-round human capital, as it is instead the case of dual educational systems (for a more in-depth analysis of the youth experience gap and a classification of school-to-work transition regimes, see Pastore, 2015).

The job competition model, brought to the fore, for the first time, by Lester C. Thurow (1979), on the other side, helps understanding the persistence of overeducation also among the adults. In this case, excess schooling is a consequence of the competition for jobs in presence of rigidity of the demand for highly educated labour that leads graduates to accumulate education, which is in some cases more than that requested to get a job, in order to reach the best position in the queue for the job.

With the assignment theory, Sattinger (1993) attempted to reconcile the two previous theories. Like the job competition model, the model assumes that the jobs available in the economy are limited, which implies that remuneration is job specific and independent of the human capital endowment of the individual; on the other hand, like the human capital theory, it assumes that with their investment in human capital individuals are able to compete for the best job and wages are bound to be influenced by the human capital level of individuals. Overeducation arises because wages will neither be entirely related to acquired schooling and other individual attributes, like in the human capital model, nor to the nature of the job, like in the job competition and job assignment model.

The job search theoretical model assumes, instead, that unemployment is largely a voluntary choice. People accept a job offer when it brings with it a wage higher than their 
reservation wages. The most skilled graduates prefer to wait into the non-employment pool until when they get the best job offer they can. High skill individuals have higher reservation wages and wait for a longer time than the least skilled graduates, who tend to choose the first job offer they get, even if it involves overeducation. Overeducation arises because the least skilled individuals get the first job offer they can because their reservation wage is low. Albrecht and Vroman (2002), Gautier (2002), Dolado et al. (2009) and Carroll and Tani (2013) are examples of this stream of the literature.

Overeducation may result also from career mobility theories (Sicherman and Galor, 1990; Büchel and Mertens, 2000): wages tend to grow over time together with the work experience accumulated by individuals. It is therefore physiological that firms and graduates generate jobworker matches with low earnings in the short run, but good career prospects in the long-run.

\section{The empirical literature}

While early studies have focused on the USA (Freeman, 1976), more recently, overeducation and skill-mismatch patterns have been noted also in other economies, including several European countries (see, for overviews, Büchel et al., 2003; Rubb, 2003; McGuinness, 2006; Leuven and Osterbeek, 2011) and also Italy (AlmaLaurea 2005; Di Pietro and Urwin 2006; Ordine and Rose, 2009; Ortiz 2010). These studies have addressed the following issues:

a) Size and cross-country determinants of overeducation;

b) Within-country determinants and by educational qualification;

c) Penalty in terms of earnings and employment probabilities;

d) Shortcomings of OLS and corrections for measurement errors, sample selection and endogeneity bias.

Issue a) is one of the most complex to deal with, due to the lack of comparative data. In addition, whatever the measure of overeducation / overskilling adopted, measurement errors are very common, inviting to take the greatest caution when studying this form of educational / skill mismatch (see, among others, Chevalier, 2003; and the recent survey by Leuven and Oosterbeek, 2011).

As seen before expectations based on theoretical reasoning and early evidence on the skill mismatch across OECD countries (Manacorda and Petrongolo, 2000) point to lower overeducation in the EU as compared to the USA. Nonetheless, supply side considerations suggest that also in (Southern) European countries, overeducation might have become an issue in recent years, due to the dramatic increase in the supply of human capital in a context of sluggish economic growth and innovation rates. The human capital boom has been the 
consequence also of policy intervention. Continuous reforms of the educational system starting from 1999 have been aimed, among others, at reducing the direct and indirect cost of education, in order to favour the increase in educational attainment.

A recent, but flourishing stream of literature is attempting to estimate the relative impact of demand and supply side variables in cross-country panel data analyses. The authors find that demand side variables and differences in the imbalances between the composition by field of study of the demand for and supply of education are more important than institutional factors (Davia et al., 2010; Verhaest and van der Velden, 2010; Croce and Ghignoni, 2012).

As to point b), overeducation is typically attributed to similar observed characteristics, such as holding a degree in the Arts or Social Sciences, the fact of studying and working, the tendency to work before starting to attend a university programme.

Even if the return to education (Point $\mathrm{c}$ ) is still positive for the overeducated and higher than that obtained by workers holding only a secondary high school diploma (Brynin and Longhi, 2009; Franzini Raitano 2012; Wasmer et al, 2005), nonetheless, they invariably get a wage penalty for being overeducated as compared to their peers employed in positions for which they hold the required diploma. Leuven and Oosterbeek (2011) report a low wage penalty associated to overeducation of less than $10 \%$ as compared to the return to required schooling.

Moreover, generally speaking, the wage gap for overskilling is lower than that for overeducation (see, among others, Sloane et al., 1999; Wasmer et al., 2005). The greater probability of overrating overskilling as compared to overeducation might explain this. In addition, overeducation is more likely to signal an objective disadvantage at the work place. Dolton and Silles (2008) find a wage penalty of about $16 \%$ for overskilling and of $23 \%$ for overeducation. McGuinness and Sloane (2010) find an average wage penalty associated to overskilling of about $10 \%$, but of about $30 \%$ in the case of overeducation in a sample of seven EU countries, using the REFLEX dataset ${ }^{3}$.

The points c) and d) appear more and more closely related to each other, since many authors have raised the concern that simple OLS estimates tend to dramatically underestimate the wage penalty associated to overeducation. Three types of possible sources of bias have been highlighted in the literature: a) endogeneity; b) sample selection; c) measurement errors. While endogeneity tends to generate upward corrections of the wage penalty, and measurement errors tend to generate a downward correction, sample selection bias has a potentially ambiguous effect.

\footnotetext{
${ }^{3}$ REFLEX is a survey carried out among a representative sample of graduate from tertiary education, having got the degree in the academic year 1999/2000, in 16 European countries (Allen and van der Velden, 2007).
} 
Measurement errors might tend to reduce the wage penalty since often individuals believe, subjectively, more than they do objectively, to be overeducated (or also overskilled) when they are not. This might tend the wage penalty of the overeducated to be lower on average, since it is computed also on individuals that are not genuinely overeducated. It is important to detect the cases of measurement errors to understand whether and how many individuals are not overeducated. In fact, as the measurement based on statistical overeducation shows, there are also many cases of under-education. If not adequately accounted for, they might tend to overestimate the wage penalty associated to overeducation, since the baseline group of the non overeducated might possibly include also the undereducated, whose wage is proven to be lower than average. Chevalier (2003), Mavromaras et al. (2010) and Pecoraro (2011) elaborate ways to measure the wage effect of genuine versus apparent overeducation by looking at the relation between overeducation and job satisfaction.

Endogeneity arises if overeducation is assumed to be related to unobserved characteristics, such as a lower level of skills and motivation of the overeducated. Now, if the overeducated are less motivated than average, it is likely that the wage penalty is higher than that typically found. In fact, once controlling for unobserved motivation and skills, overeducation should generate a greater wage penalty.

Nicaise (2001) is among the first to notice that ignoring the non-employed might generate a bias on returns to education whose direction is in principle ambiguous. Applying her line of reasoning to the case of overeducation, as represented in Figure 1, according to the job competition and job assignment models, sample selection bias arises because of the fact that the educational mismatch appears first of all in the form of a higher probability of non-employment and only at a later stage takes the form of a wage penalty. Once controlling for the selection bias arising from the presence of non-employment, the wage penalty of those experiencing an educational mismatch might be much higher. Conversely, according to the search theoretical model, unemployment is a voluntary choice and the most skilled graduates prefer to wait into non-employment until when they get the best job offer they can. Accordingly, sample selection causes an upward bias in OLS estimates.

\section{[Figure 1 about here]}

Once controlling for endogeneity and sample selection bias, most authors find that the wage penalty associated to overeducation increases lending support to the job competition and job assignment models (see, among others, Cutillo and Di Pietro, 2006). In addition, the upward bias tends to outweigh the downward bias due to measurement error in panel data analysis (Dolton and Silles, 2008). 


\section{The case of Italy}

The empirical literature on Italy has especially aimed at catching the specificity of the country, namely its low level of both demand and supply of human capital. From the demand side, Manacorda and Petrongolo (2000), among others, note that the production structure is still based on labour intensive traditional manufacturing. Therefore, the origin of educational mismatch could be found in the weak demand of more educated workers compared with the skill formation supplied by the educational system (Cainarca and Sgobbi, 2009). From the supply side, Checchi (2003), Pastore (2009) and Franzini and Raitano (2012), among others, note the lowest level and quality of educational attainment of young people as compared to the EU average ${ }^{4}$.

A large literature points to the inefficiency of the educational system in generating a sufficient level and composition of skills for the labour market demand. Ordine and Rose (2009), for example, model the hypothesis that inefficient educational choices due to the different educational quality supplied by the universities can generate overeducation. It is mirrored not only in the low level of education attainment, but also in the dramatic social immobility. Education attainment is especially low among the poorest segments of the population, due to school tracking (see, among others, Checchi et al., 1999; Cappellari, 2004; Brunello e Checchi, 2007; Bratti et al., 2008; Checchi, 2010). In addition, Caroleo and Pastore (2012) note a strong correlation between the father educational level and that of their children by type of university degree: in particular, most children whose parents both hold a university degree tend to gather in those fields of study that give access to liberal professions, where the intergenerational transfer of human capital is greatest.

All this considered, in principle, it is hard to say whether overschooling is higher or lower than elsewhere. ISTAT, the Italian national statistical office, estimated that the undereducated were 1.9 million (9\% of employment), whereas the overeducated amounted to 3.7 million $(16.5 \%)$ in 2006 . The existing comparative evidence hints that the country has a higher than average share of overeducated workers, suggesting that demand is more at risk of losing the race with the supply of human capital than elsewhere. Horizontal overeducation might also be an important component, due to the low degree of orientation of high school diploma students, the

\footnotetext{
${ }^{4}$ In the last decade, Italy has witnessed several reforms of the university system aimed at reducing the indirect cost of education, one of the highest in the world, due to the long time that is necessary to attain a degree and complete the school-to-work transition (Pastore, 2009). As a consequence, the number of graduates has slightly increased, although at a slower pace than the EU average, making the country still score as one of the lowest in terms of educational levels in Europe.
} 
scant integration of the educational system with the labour market and the high share of graduates in humanities and other arts degrees.

In their study of the REFLEX data, McGuinness and Sloane (2010, Table 3.6) find that the extent of the educational mismatch is in Italy one of the highest among the EU countries included in their sample (Davia et al., 2010; Verhaest and van der Velden, 2010). With a share of $23 \%$ of overeducated workers at the time of their first job and of $13 \%$ five years after graduation, Italy is the third last performer, standing only after Spain and the UK, that have a share of overeducation equal to $17 \%$ and $14 \%$, respectively, five years after graduation. In other EU countries in the sample, overeducation is almost always under the threshold of $10 \%$.

Slightly different is the case of overskilling, which is much more common in the REFLEX sample and for which Italy tends to the country average. This is due to the tendency of overskilling to be much more common than overeducation. In Italy, overskilling equals $21 \%$ at the first job and $11 \%$ five years after graduation. Italy is still under Spain and the UK only, but this time also other countries have similar levels, fluctuating from $8 \%$ in Portugal and Norway to $19 \%$ in Belgium and $21 \%$ in France.

Ferrante (2010) uses AlmaLaurea data to assess the impact of a number of individual characteristics on the effectiveness of the university degree in providing a job that is up to the educational and skill level of the individual. He reports that the variables that correlate positively and in a statistically significant way with the effectiveness of the university degree in an ordered probit framework include: a high school diploma with a score of 55-60 out of 100; a high university final grade; a longer length of job search; experiencing some postgraduate training; holding a university degree in engineering, chemistry and pharmacy, law. The negative and statistically significant determinants include: holding a diploma of technical high school, rather than gymnasium; belonging to the working class; starting their career via starter or atypical working contracts, such as apprenticeship, stage, temporary contract; holding an arts degree or a degree in education, psychology, social sciences. Moreover, the author finds a statistically significant positive effect of the effectiveness of the university degree on job satisfaction.

The wage penalty of overeducated or overskilled university graduates is found to be lower in Italy than in other countries and in some case not statistically significant (Wasmer et al. 2005; Brynin and Longhi 2009; Ordine and Rose, 2009). Using the 2001 ISTAT enquiry on professional integration of 1998 graduates, Cutillo and Di Pietro (2006) find a wage penalty for university graduates ranging between $2.4 \%$ and $5.7 \%$ in simple OLS estimates based on an ISTAT database. McGuinness and Sloane (2010) find a wage penalty of about $10 \%$. Interestingly, in the case of Italy, they find a higher wage penalty for the overskilled $(-11 \%)$ 
than for the overeducated (-4\%). The latter is not statistically significant. They also find a wage penalty of about $8 \%$ in the case of under-skilling.

Using the ISFOL PLUS data, Aina and Pastore (2012) find a strong correlation of overeducation with delayed graduation and a wage penalty associated to overeducation of about $20 \%$, slightly higher than in previous studies.

According to some authors, the return to education of overeducated graduates is anyway positive even if lesser than that of well-matched counterparts (Caniarca and Sgobbi 2009; Franzini and Raitano 2012). This suggests the low wage penalty associated to the educational and skill mismatch suggests that firms have strong incentives to hire a worker holding a university degree rather than a high secondary school diploma even if the university graduate is bound to remain overeducated. This can be understood considering the highest unemployment rate existing traditionally in the country and the abundance of non-employed job seekers especially among the youngest segments of the population. Although lower than that among young people holding a high school diploma, the unemployment rate of university graduates is higher in Italy than in other EU countries. As already noted in the previous section, this poses an apparent problem of sample selection bias when estimating the wage effect of overeducation and seems to line in favour of the job competition and job assignment models, rather than the job search theoretical model.

Using an ISTAT survey carried out in 2001 on graduates in 1998, Cutillo and Di Pietro (2006) find that once controlling for endogeneity of overeducation, the wage penalty increases up to between 22 and 39\%. Once controlling for both endogeneity and sample selection bias, the wage penalty of overeducation reaches always about $40 \%$, independent of the sample adopted.

Considering the dramatic geographical differences existing in the country, a potentially relevant issue is whether there is any divide also in the way overeducation manifest itself across regions. In theory, one would expect overeducation to be more common in the South, where the demand for skills is supposedly lower, due to the lower development level. Nonetheless, Franzini and Raitano (2012) find that in the Southern regions overeducation is less frequent and bears a lower wage penalty. They explain this finding in terms of the relatively greater share in Southern regions of workers employed in the state sector, where overeducation is less frequent and bears a lower wage penalty. On the other hand Croce and Ghignoni (2015) find that frictions and barriers increasing the costs of spatial mobility worsen the matching between required and possessed education in the labour market. And, in particular, among the university graduates, movers are less overeducated than stayers and a longer migration distance decreases overeducation risks. 


\section{Overeducation in the AlmaLaurea data}

Caroleo and Pastore (2013) provide a detailed empirical analysis on the overeducation in Italy using the AlmaLaurea data bank that provides an excellent testing ground to address this issue and to test different theoretical approaches ${ }^{5}$. Their conclusions about the personal attributes of overeducated are in line with those of the previous literature.

In particular, Table 1 provides summary measures of the wage gap derived from different estimated models, including the unconditional estimate, the conditional one and that obtained including controls for sample selection bias. They estimate the unconditional wage penalty both using a traditional OLS specification and the regression with intervals considering how wages are measured in the data.

The unconditional wage gap is relatively high for both overeducation (from -21 to $-25 \%$ ) and overskilling (from -16 to $-21 \%$ ). In both cases, OLS underestimates the wage penalty as compared to interval regression.

However, the unconditional measure of the wage penalty might catch such factors as the lower than average productivity characteristics of the overeducated / overskilled. In other words, such a high unconditional penalty might disappear once controlling for the lower than average levels and quality of human capital of the overeducated. Such characteristics might be observed or unobserved.

Table 1 reports also conditional measures of the wage penalty as obtained in OLS estimates and in interval regressions including all the variables of the AlmaLaurea data base as controls. Interestingly, once controlling for the level and quality of human capital, both OLS coefficients are halved. More precisely, the wage penalty of overeducation reduces to $12 \%$ and that of overskilling to $7 \%$. Similar reductions are observed in the case of interval regressions.

\section{[Table 1 about here]}

Our findings provide indirect support for the job competition and the job assignment model versus the search theoretical model, suggesting that the non-employed would be more likely to be overeducated if they found a job. In other words, the sample selection correction confirms that there is positive selection into employment of the most skilled among those experiencing

5 AlmaLaurea is a consortium including a large and growing number of Italian universities. The aim of the consortium is to provide a framework to ease the interaction of graduates and firms by collecting the curricula of graduates and making them available to firms wishing to fill in their job vacancies. A further support is supplied to the universities providing them with homogenous information on the quality of the achieved education. It also collects valuable information on individual and educational characteristics of graduates at the time of graduation and on their employment status after one, three and five years from graduation. 
the educational / skill mismatch with respect to labour demand. This finding is partly in line with that of Cutillo and Di Pietro (2006) based on different data.

\section{Concluding remarks}

This essay provides a detailed survey of the literature on overeducation, attempting to elaborate an interpretation of the educational mismatch as linked to both insufficient demand for skills and the inefficiency of the school-to-work transition in producing the skills that the labor market requires.

The literature on the role of demand side factors is still tentative, since most of the literature is based on a micro-economic approach and on individual level data. The interpretation proposed in some recent contributions is that the insufficient demand for skills especially after an expansion of the supply of skills, as the one which is happening in Europe in the last two decades, is an obvious factor of overeducation in most countries. Nonetheless, as also the most recent theory of endogenous technical change would predict, an expansion of the supply of skills might be followed by a process of technological innovation which could develop, in turn, also the demand for skills. In other words, the educational and skill mismatch would be temporary phenomena which will be absorbed when the economy returns to grow.

Then, it is likely that the technological poverty of many EU countries, especially in the Southern area, explains most part of the educational mismatch, especially that in terms of overskilling. This is especially true in those countries, like Italy, where the production system is oriented towards traditional manufacturing sectors and therefore the demand for human capital is expected to remain low and stable.

We have argued that overeducation in this country is also associated with an inefficient school-to-work transition system which does not allow young people to develop their work related skills, because of the lack of links between the educational system and the labor market.

Special mention has been made of the research works on the wage penalty associated with overeducation for individuals and therefore from a microeconomic point of view. The results show a relatively high unconditional wage penalty for both overeducation and overskilling, partially offset once controlling for the lower than average levels and quality of human capital of the overeducated.

The policy implications of our analysis is that, taking for granted the necessity of policies takling the low productivity growth rate, it is important also to advance the school to work transition system and in particular the links of the educational and training systems to the labor market. In this sense, it is important that the dual principle be introduced and diffused also in 
tertiary education. Alternatively, more job opportunities and insertion contracts should be offered to fresh graduates, so to develop sooner their work related skills. 


\section{References}

Acemoglu, D. (2002), "Technical change, inequality and the labor market", Journal of Economic Literature 40(1): 7-72.

Aina, C. and F. Pastore (2012), "Delayed Graduation and Overeducation: A Test of the Human Capital Model versus the Screening Hypothesis", IZA discussion paper, n. 6413.

Albrecht, J. and S. Vroman (2002), “A Matching Model with Endogenous Skill Requirements", International Economic Review, 43: 283-305.

Allen, J. and R. van der Velden, (eds.) (2007), The Flexible Professional in the Knowledge Society: General Results of the REFLEX Project, Research Centre for Education and the Labour Market, University of Maastricht, Maastricht.

Alma Laurea (2005), Lavorare dopo la laurea. Caratteristiche e percorsi occupazionali, Il Mulino, Bologna.

Barone, C and L. Ortiz (2011), "Overeducation among European University Graduates: A Comparative Analysis of its Incidence and the Importance of Higher Education Differentation" Higher Education, 61(3): 325-337.

Becker, G. S. (1964), Human Capital, Columbia University Press, New York.

Bratti, M., Checchi D. and G. de Blasio (2008), "Does the Expansion of Higher Education Increase the Equality of Educational Opportunities? Evidence from Italy", Labour, 22(special issue): 53-88.

Brunello, G. and D. Checchi (2007), "Does School Tracking Affect Equality of Opportunity? New International Evidence", Economic Policy, 22(52): 781-861.

Brynin, M. and S. Longhi (2009), "Overqualification: Major or minor mismatch?", Economics of Education Review, 28(1): 114-121.

Büchel F. and A. Mertens (2004), "Overeducation, undereducation, and the theory of career mobility”, Applied Economics, 36(8): 803-816.

Büchel, F., de Grip A. and A. Mertens (eds.) (2003), Overeducation in Europe, Edward Elgar, Cheltenham.

Cainarca, G.C. and F. Sgobbi (2009), "Quanto paga studiare: la relazione fra istruzione e retribuzione in Italia" Economia Politica, XXVI(1): 53-84.

Cappellari, L. (2004), "The Effects of High School Choices on Academic Performance and Early Labour Market Outcomes", Royal Economic Society Annual Conference, Royal Economic Society.

Caroleo, F.E. and F. Pastore (2012), "Talking about the Pigou Paradox. Socio-Educational Background and Educational Outcomes of AlmaLaurea", International Journal of Manpower, 33(1): 27-50.

Caroleo, F.E. and F. Pastore (2013), "Overeducation at a Glance: Determinants and Wage Effects of the Educational Mismatch, Looking at the AlmaLaurea Data", IZA Discussion Paper, No. 7788.

Carroll D. and M. Tani (2013), "Job Search as a Determinant of Graduate Over-Education: Evidence from Australia”, IZA Discussion Paper, No. 7202. 
Castellano, R., Quintano C. and A. D'Agostino (2008), Graduates in Economics and Educational Mismatch: the Case Study of the University of Naples "Parthenope", Journal of Education and Work, 21(3): 249-271.

Checchi, D. (2003), "The Italian Educational System: Family Background and Social Stratification", in ISAE (ed.), Monitoring Italy, ISAE, Rome.

Checchi, D. (ed.) (2010), Immobilità diffusa: Perché la mobilità intergenerazionale è così bassa in Italia, Il Mulino, Bologna.

Checchi, D., Ichino A. and A. Rustichini (1999), "More Equal but Less Mobile? Education Financing and Intergenerational Mobility in Italy and in the US", Journal of Public Economics, 74(3): 351-393.

Chevalier, A. (2003), "Measuring Over-education”, Economica, 70(279): 509-531.

Croce, G. and E. Ghignoni (2015), "Educational mismatch and spatial flexibility in Italian local labour markets", Education Economics, 23(1): 25-46.

Croce, G. and E. Ghignoni (2012), "Supply and Demand of Skilled Labour and Overeducation in Europe: A Country Level Analysis", Comparative Economic Studies, 2012(54): 413-439.

Cutillo, A. and G. Di Pietro (2006), "The effects of overeducation on wages in Italy: a bivariate selectivity approach”, International Journal of Manpower, 27(2): 143-168.

Davia, M.A., McGuinness S. and P.J. O’Connell (2010), Explaining international differences in rate of overeducation in Europe, ESRI working paper, n. 365.

Di Pietro, G. and P. Urwin (2006), "Education and Skills Mismatch in the Italian Graduate Labour Market", Applied Economics, 38(1): 79-93.

Dolado J.J., Jansen M. and J.F. Jimeno (2009), " On- the-Job Search in a Matching Model with Heterogeneous Jobs and Workers", The Economic Journal, 119:200-228.

Dolton, P. and M.A. Silles (2008), "The Effects of Overeducation on Earnings in the Graduate Labour Market”, Economics of Education Review, 27(2): 125-139.

Ferrante, F. (2010), “«Educational / skill mismatch»: cosa ci dicono i dati AlmaLaurea?”, in AlmaLaurea, XII Rapporto sulla condizione occupazionale dei laureati. Investimenti in capitale umano nel future di Italia ed Europa, Il Mulino, Bologna.

Freeman, R. (1976), The Overeducated American, Academic Press, New York.

Franzini, M. and M. Raitano (2012), "Few and underutilized? Overeducation of Italian graduates", in E. Mandrone E. (ed) Labour Economics: PLUS Empirical Studies, ISFOL, Temi e Ricerche 3, Ediguida, Cava dè Tirreni.

Galasi, P. (2008), "The effect of educational mismatch on wages for 25 countries", Corvinus University of Budapest, Budapest Working Papers On The Labour Market, n. 8.

Gautier, P. A. (2002), "Non-sequential search, screening externalities and the public good role of recruitment offices," Economic Modelling, 19(2):179-196. 
Ghignoni, E. and A. Verashchagina (2013), "Educational qualifications mismatch in Europe. Is it demand or supply driven?" Journal of Comparative Economics, http://dx.doi.org/10.1016/j.jce.2013.06.006.

Leoni, R. (2011), "Employability of graduates and development of competencies: mind the gap and mind the step! Empirical evidence for Italy", Quaderni di ricerca del Dipartimento di Scienze Economiche "Hyman P. Minsky", n. 1.

Leuven, E. and H. Oosterbeek (2011), "Overeducation and Mismatch in the Labour Market", in E. A. Hanushek, S. Machin and L. Woessmann (eds.), Handbook of the Economics of Education, Chap. 3: 283-326.

Manacorda, M. and B. Petrongolo (2000), "Skill Mismatch and Unemployment in OECD Countries", Wirtschaftspolitische Blatter, 47(1): 72-82.

Mavromaras, K. G., McGuinness, S., O’Leary, N. C., Sloane, P. J., and Wei, Z. (2010), “Job mismatches and labour market outcomes: Panel evidence on Australian university graduates", IZA Discussion Papers n. 5083.

McGuinness, S. (2006), "Overeducation in the labour market", Journal of Economic Surveys, 20(3): 387-418.

McGuinness, S. and P.J. Sloane (2010), “«Educational / skill mismatch» nel mercato del lavoro dei laureate: un'analisi comparata", in AlmaLaurea, XII Rapporto sulla condizione occupazionale dei laureati. Investimenti in capitale umano nel future di Italia ed Europa, Il Mulino, Bologna, pp: 101-115.

Manacorda, M. and B. Petrongolo (2000), "Skill Mismatch and Unemployment in OECD Countries", Wirtschaftspolitische Blatter, 47(1): 72-82.

Nicaise, I. (2001), "Human capital, reservation wages and job competition: Heckman's lambda reinterpreted", Applied Economics,33(3):309-315.

Nordin, M., Persson, I. and Rooth, D. O. (2010), "Education-Occupation Mismatch: Is There an Income Penalty?", Economics of Education Review, 29(6): 1047-1059.

Ordine, P. and G. Rose (2009), "Overeducation and Instructional Quality: a Theoretical Model and Some Facts", Journal of Human Capital, 3(1): 73-105.

Ortiz, L. (2010), "Not the right job, but a secure one: overeducation and temporary employment in France, Italy and Spain", Work, employment and society, 24(1): 47-64.

Pastore, F. (2009), "School-to-Work Transitions in Italy. A Steeplechase with no Winner?", paper presented at the XXIV AIEL Conference, University of Sassari,.

Pastore, F. (2015), "The Youth Experience Gap. Explaining National Differences in the Schoolto-Work Transition", Springer Briefs, Heidelberg.

Pecoraro, M. (2011), "Is there Still a Wage Penalty for being Overeducated but well-matched in Skills? A Panel Data Analysis of a Swiss Graduate Cohort", ," Université catholique de Louvain, Institut de Recherches Economiques et Sociales (IRES) Discussion Papers, n. 19.

Robst, J. (2007), "Education and Job Match: The Relatedness of College Major and Work", Economics of Education Review, 26(4): 397-407.

Rubb, S. (2003), "Overeducation in the Labour Market: A Comment and a Re-Analysis of a Meta-Analysis", Economics of Education review, 22(6): 621-629.

Sattinger, M. (1993), "Assignment models of the distribution of earnings", Journal of Economic Literature, 31(1): 851-80. 
Schivardi, F. and R. Torrini (2011), "Cambiamenti strutturali e capitale umano nel sistema produttivo italiano", Banca d'Italia, Questioni di Economia e Finanza (Occasional papers), n. 108.

Sicherman, N. and O. Galor (1990), "A theory of career mobility", Journal of political economy, 2(1):169-192.

Sloane, P. (2003), "Much Ado about Nothing? What does the Overeducation Literature really Tells us?", in Büchel, F., A. de Grip and A. Mertens (op. cit.).

Sloane, P., Battu H. and Seaman P. (1999) "Overeducation, undereducation and the British labour market", Applied Economics, 31(11):1437-1453.

Thurow, L. C. (1979), “A Job-Competition Model”, In: Piore, M. J. (Ed.): Unemployment and Inflation: Institutionalist and Structuralist Views. New York, 17-32.

Verhaest D., van der Velden R., 2010, Cross-country differences in graduate overeducation and its persistence, ROA Research Memorandum 7, Maastricht University.

Wasmer E., Fredriksson P., Lamo A., Messina J., Peri G. (2005), "The Macroeconomics of Education", Fondazione Rodolfo De Benedetti Report, Milan. 


\section{Appendix of Tables and Figures}

Table 1. The wage penalty of overeducation and overskilling

\begin{tabular}{|c|c|c|}
\hline & $\begin{array}{l}\text { Overeducation } \\
\text { (to get) }\end{array}$ & $\begin{array}{l}\text { Overskilling } \\
\text { (to do) }\end{array}$ \\
\hline $\begin{array}{l}\text { Dependent variable: } \\
\text { Natural logarithm of net monthly wages }\end{array}$ & (1) & (2) \\
\hline \multicolumn{3}{|l|}{ Unconditional estimates } \\
\hline \multirow{2}{*}{$\begin{array}{l}\text { OLS } \\
\text { Interval regression }\end{array}$} & $-0,2081 * * *$ & $-0,1568 * * *$ \\
\hline & $-0,2463 * * *$ & $-0,2088 * * *$ \\
\hline \multicolumn{3}{|l|}{ Conditional estimates } \\
\hline$O L S$ & $-0,1220 * * *$ & $-0,0692 * * *$ \\
\hline Interval regression & $-0.1319 * * *$ & $-0.0967 * * *$ \\
\hline Number of observations & 16591 & 16591 \\
\hline Controlling for sample selection bias & \multicolumn{2}{|c|}{ Without instrumental variables } \\
\hline Heckman model (ML simultaneous) & $-0,1335^{* * *}$ & $-0,0758 * * *$ \\
\hline \multirow[t]{2}{*}{ Heckman model (two steps) } & $-0,1336$ *** & $-0,0758 * * *$ \\
\hline & \multicolumn{2}{|c|}{$\begin{array}{c}\text { With instrumental variables } \\
\text { (parents' education) }\end{array}$} \\
\hline Heckman model (ML simultaneous) & $-0.1225 * * *$ & $-0,0758^{* * * *}$ \\
\hline Heckman model (two steps) & $-0,1337 * * *$ & $-0,0759 * * *$ \\
\hline Number of observations & 21605 & 21605 \\
\hline
\end{tabular}

Note: The table reports only the coefficients of interest. The OLS conditional estimates are obtained with all the control variables included in Table 4. The Heckit based on Maximum Likelihood simultaneous estimate are obtained with all the control variables included in Table 6. The two step estimates are unreported. Legend: * $p<0.05 ; * * p<0.01 ; * * * p<0.001$

Source: own elaboration on AlmaLaurea data. 
Figure 1. Heckman correction of the wage effect of overeducation/overskilling Panel (a): Job competition, job assignment and human capital model

Earnings

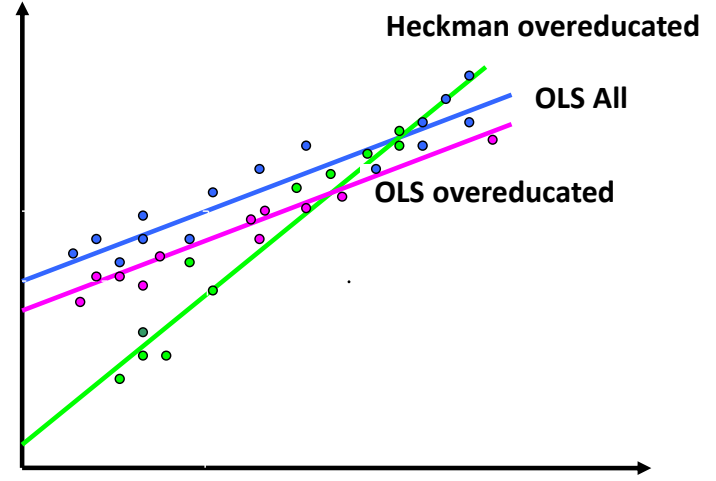

Years of Education

Panel (b): Job search model

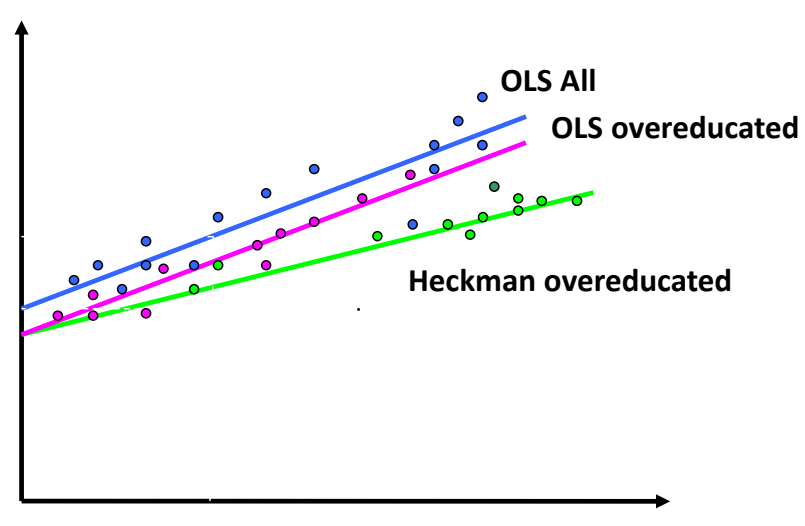

Years of education 


\begin{tabular}{|c|c|c|c|}
\hline & Data & Overeducation indicator & results \\
\hline $\begin{array}{l}\text { Quintano, } \\
\text { Castellano, } \\
\text { D'Agostino (2008) }\end{array}$ & $\begin{array}{l}\text { Sample of graduates in } \\
\text { Economics at University } \\
\text { of Naples Parthenope by } \\
\text { graduation year (1999- } \\
\text { 2002). Date of interview: } \\
\text { spring } 2005\end{array}$ & $\begin{array}{l}\text { The authors derive two indicators from the self-declared answers } \\
\text { to the questionnaire. a) overskilling or Objective indicator (i.e. } \\
\text { the formal necessity of having the university degree in order to } \\
\text { apply for the job). b) overeducation or Combined indicator: who } \\
\text { respond that university degree is not formally necessary plus all } \\
\text { graduates who feel that the substantial need of a university } \\
\text { degree is excessive. Earning indicator: dichotomous measure that } \\
\text { divides more disadvantaged graduates from the others (+ or - } \\
1100 € \text { per month) }\end{array}$ & $\begin{array}{l}\text { To be overeducated is a strong predictor of the } \\
\text { probability of having low earning. ( } 0.39 * \text { for the } \\
\text { objective Ind.) }\left(0,44^{*} \text { for the combined ind.) }\right.\end{array}$ \\
\hline $\begin{array}{l}\text { Ferrante, } \\
\text { McGuinnes, } \\
\text { Sloane (2010) }\end{array}$ & $\begin{array}{l}\text { Alam Laurea: Sample } \\
(17000) \text { of the graduate } \\
\text { population in Italy in } 2004 \\
\text { interviewee in } 2009 .\end{array}$ & $\begin{array}{l}\text { Indicator of overskilling or effectiveness: if skills acquired during } \\
\text { university are utilized in the present job. Indicator of } \\
\text { overqualification: if the degree level is necessary or useful to do } \\
\text { the job. Indicator of efficacy: combination of effectiveness } \\
\text { indicator plus overqualification indicator. Earning indicator: not } \\
\text { defined }\end{array}$ & $\begin{array}{l}\text { Results of the mismatch indicators on the } \\
\text { probability to be employed are not presented. } \\
\text { Descriptive statistics show that } 11 \% \text { of the } \\
\text { graduates employed are overskilled and } 7 \% \text { are } \\
\text { overqualified five years after the degree. }\end{array}$ \\
\hline $\begin{array}{l}\text { Ferrante, McGuinnes, Sloane } \\
\text { (2010) }\end{array}$ & $\begin{array}{l}\text { International data set } \\
\text { REFLEX. Graduate in } \\
1999 / 2000 \text { in } 13 \\
\text { European countires } \\
\text { interviewee in } 2005\end{array}$ & $\begin{array}{l}\text { Overeducated who feel for a present job more adequate a title } \\
\text { lesser than a university degree (vertical mismatch). Overkilled: if } \\
\text { skills acquired during university are not utilized in the present job } \\
\text { (horizontal mismatch). Earning indicator: wage level (si parla di } \\
\text { earning equation e di livelli retributivi) }\end{array}$ & $\begin{array}{l}\text { In Italy the wage penalty of the overeducated is } \\
\text { not significant }(-0,04) \text {. In the other countries the } \\
\text { coefficent is high and significant. To be } \\
\text { overskilled has a wage penalty significative and in } \\
\text { line with the other countries sach as France, } \\
\text { Netherland end UK }\left(-0,11^{* *}\right)\end{array}$ \\
\hline $\begin{array}{l}\text { Franzini and } \\
\text { Raitano (2009) }\end{array}$ & $\begin{array}{l}\text { Data Set Plus. Survey of } \\
\text { 2005. Sub-sample of all } \\
\text { dependent full time } \\
\text { workes }\end{array}$ & $\begin{array}{l}\text { Overeducation or subjective direct indicator (i.e. the formal } \\
\text { necessity of having the university degree in order to apply for the } \\
\text { job). Earning indicator: ORU (Overeducation Required } \\
\text { Undereducation model) Method, based on the surplus years of } \\
\text { education i.e. the difference between the mode years of } \\
\text { education of the qualification held and of the one required for } \\
\text { the job. }\end{array}$ & $\begin{array}{l}\text { To have a university degree augments the } \\
\text { probability of higher wages }\left(21,65^{* * *}\right) \text {. To be not } \\
\text { overedutated performs better }\left(22,64^{* * *}\right) \text {. To be } \\
\text { overeducated performs lesser than to be not } \\
\text { overeducated }\left(17,02^{* * *}\right) \text { but the coefficient is } \\
\text { positive. This if we refer to the all dependent full } \\
\text { time workers. The overeducated dependent full } \\
\text { time workers with university degree have a wage } \\
\text { penalty of }-5,15 \% * * * \text {. But this decrease and } \\
\text { become not significative when we add indices of } \\
\text { individual abilities. }\end{array}$ \\
\hline $\begin{array}{l}\text { Brynin and } \\
\text { Longhi (2009) }\end{array}$ & $\begin{array}{l}\text { The data derive from the } \\
\text { "e-Living project" funded } \\
\text { by }\end{array}$ & $\begin{array}{l}\text { Three indicators: the first wirh the 'certification method' is best } \\
\text { calculated from a direct comparison of qualifications held and } \\
\text { required. The second method is a version of the traditional ORU }\end{array}$ & $\begin{array}{l}\text { The results of the estimation wiht the } \\
\text { certification indicator show in all countries } \\
\text { except Germany a matched graduate earns more }\end{array}$ \\
\hline
\end{tabular}




\begin{tabular}{|c|c|c|c|}
\hline & $\begin{array}{l}\text { the EU. The project was } \\
\text { based on a household } \\
\text { survey of } 1750 \\
\text { households in } 4 \\
\text { countries-Britain, } \\
\text { Germany, Italy, and } \\
\text { Norway }\end{array}$ & $\begin{array}{l}\text { specification: it defines excess education as the difference } \\
\text { between actual years of education and the average years } \\
\text { associated with the qualification necessary for a job. The third is } \\
\text { the 'Combined' definition: the (temporal) overeducation is the } \\
\text { difference in years of education between individual i and the } \\
\text { majority of people with the same qualification. }\end{array}$ & $\begin{array}{l}\text { than an overqualified graduate (in Italy we have } \\
\text { the higher coefficients ( } 0,922 \text { vs } 0,719 \text { ). In all } \\
\text { countries except Norway (where the difference is } \\
\text { slight), someone matched with a higher school } \\
\text { leaving qualification earns more than someone } \\
\text { overqualified at the same level. Certification } \\
\text { indicator in Italy generates a premium. The } \\
\text { results of ORU specification reveal that in all four } \\
\text { countries the effect of education required for the } \\
\text { job is positive, also greater than that of years of } \\
\text { education, The effects of excess education are } \\
\text { either positive, but with little statistical } \\
\text { significance, or zero. Combined definition: In } \\
\text { Italy nor excess qualifications (converted into } \\
\text { years of education) nor extra time in education } \\
\text { have effect on earnings }\end{array}$ \\
\hline $\begin{array}{l}\text { Di Pietro } \\
\text { and Urwin (2006) }\end{array}$ & $\begin{array}{l}\text { The data are taken from a } \\
\text { survey carried out by } \\
\text { ISTAT (National Statistical } \\
\text { Italian } \\
\text { Centre) in } 1998 \text { on } \\
\text { individuals who } \\
\text { graduated from all Italian } \\
\text { universities in } 1995 . \\
\text { (17,326 individuals) }\end{array}$ & $\begin{array}{l}\text { Four dummy variables. The first one (EDMIS) takes a value of } 1 \text { if } \\
\text { a university degree was not a formal requirement for the } \\
\text { graduate's current job, and } 0 \text { otherwise. Similarly, the second } \\
\text { dummy variable (OVERED) has a value of } 1 \text { if the worker } \\
\text { considers their level of education to be excessive, relative to the } \\
\text { job tasks they have to perform, and } 0 \text { otherwise. The third } \\
\text { dummy variable (UNDERED) takes a value of } 1 \text { if a worker feels } \\
\text { that their level of education is insufficient, relative to the job } \\
\text { tasks. Finally, with respect to skill mismatch, it has been } \\
\text { constructed a dummy variable (SKIMIS) which takes the value } 1 \text { if } \\
\text { graduates respond that they have used either "none" or "a little" } \\
\text { of the knowledge and skills acquired at university in their current } \\
\text { jobs, and } 0 \text { otherwise. }\end{array}$ & $\begin{array}{l}\text { The coefficient on over-education (OVERED) is } \\
\text { found to be negative and statistically significant, } \\
\text { whereas that on under-education (UNDERED) is } \\
\text { neither in line with expectations nor statistically } \\
\text { significant. The results indicate that over- } \\
\text { qualified graduate workers earn, on average, } 5.1 \\
\text { per cent less than those with the same } \\
\text { qualification level who occupy jobs for which they } \\
\text { are adequately qualified. The indicator of skill } \\
\text { Underutilization (SKIMIS) has a negative impact } \\
\text { on earnings (1,5\%). When we combine the } \\
\text { employed indicators for education and skills } \\
\text { mismatch are combined, we fund that effect of } \\
\text { under-utilisation of skills on wages disappears } \\
\text { when controlling for educational mismatches, } \\
\text { while the value of the coefficient on over- } \\
\text { education is largely unchanged. Adding the } \\
\text { indicator for educational mismatch constructed } \\
\text { (EDMIS), the findings indicate that graduates } \\
\text { working in jobs for which a university degree was } \\
\text { not formally required, receive lower wages than } \\
\text { other graduates who occupy jobs for which a }\end{array}$ \\
\hline
\end{tabular}




\begin{tabular}{|c|c|c|c|}
\hline & & & $\begin{array}{l}\text { degree was a formal requirement. The wage } \\
\text { penalty is of } 3.6 \% \text {. }\end{array}$ \\
\hline $\begin{array}{l}\text { Di Pietro } \\
\text { and Cutillo } \\
\text { (2006), IJM }\end{array}$ & $\begin{array}{l}\text { The individual-level data } \\
\text { are taken from a survey } \\
\text { carried out in } 2001 \text { by the } \\
\text { ISTAT on people who } \\
\text { graduated from Italian } \\
\text { higher education } \\
\text { institutions in } 1998\end{array}$ & $\begin{array}{l}\text { Overeducation is measured through the worker self-assessment } \\
\text { method. Overdeducated are graduates who respond not to the } \\
\text { question: 'Was a university degree a formal requirement to } \\
\text { obtain your current job?'. The estimate effect of overeducation } \\
\text { on wage are done by a simple OLS and by IV model to take } \\
\text { account for the endogeneity of overeducation. However, it has } \\
\text { been demonstrated that, using a single selection framework, the } \\
\text { estimate effects is downwrad biased as it don't thake in account } \\
\text { the problem of sample selection bias and of endogeneity bias. To } \\
\text { go beyond the failure of controlling for this correlation yields the } \\
\text { relationship between overeducation and wages has been } \\
\text { investigated using a double selection approach where two basic } \\
\text { individuals' decisions are considered: the decision to work and } \\
\text { the choice of occupation. Wage indicator: natural logarithm of } \\
\text { the basic hourly wage }\end{array}$ & $\begin{array}{l}\text { The estimated pay penalty associated with } \\
\text { overeducation under OLS and when we correct } \\
\text { for sample selection bias due to the decision to } \\
\text { workis approximately } 4.4 \% \text {. The estimate of the } \\
\text { negative effect of overeducation on earnings rises } \\
\text { to } 39.4 \text { per cent and } 5.7 \text { per cent once we take } \\
\text { the endogeneity of overeducation into account } \\
\text { using the Heckman and the IV estimation } \\
\text { techniques respectively. The wage differential } \\
\text { between appropriately } \\
\text { educated and overeducated workers (measured } \\
\text { at the all workers mean), using the bivariate } \\
\text { selectivity model is of } 39,0 \% \text {. }\end{array}$ \\
\hline $\begin{array}{l}\text { Wasmer, Fredriksson, } \\
\text { Lamo, Messina, Peri (2005) }\end{array}$ & $\begin{array}{l}\text { The authors use the } \\
\text { European Community } \\
\text { Household Panel (ECHP) } \\
\text { Data set. The analysis is } \\
\text { concentrated on the five } \\
\text { largest countries of the } \\
\text { EU-15; namely, France, } \\
\text { Germany, Italy, Spain and } \\
\text { the UK, but also summary } \\
\text { statistics for all EU-15 } \\
\text { countries in an attempt to } \\
\text { provide a full picture of } \\
\text { the skill mismatch } \\
\text { phenomenon are } \\
\text { presented }\end{array}$ & $\begin{array}{l}\text { For indicators are used: Type 1. "Non-over-qualified and well } \\
\text { matched" (NOWM), if non-over-qualified and education and } \\
\text { training is suited for their job. Type 2. "Non-over-qualified and } \\
\text { mismatched" (NOBM), if non-over-qualified but education and } \\
\text { training is not suited for their job. Type 3. "Over-qualified but } \\
\text { correctly matched" (OWM), if over-qualified but education and } \\
\text { training are suited for their job. Type } 4 \text {. "Over-qualified and } \\
\text { mismatched" (OBM), if over-qualified and education andtraining } \\
\text { are not suited for job. Wage equation: standard Mincer } \\
\text { regression augmented to include a dummy variable for } \\
\text { overqualification and in a second stage authors differentiate } \\
\text { between the different types of mismatched workers. }\end{array}$ & $\begin{array}{l}\text { For the pooled countries overqualified workers } \\
\text { have a wage penalty with respect to properly } \\
\text { matched employees. However, the magnitude of } \\
\text { the effect is relatively small ( } 1 \text { \% lower wages) } \\
\text { Moreover, the pooled results hide important } \\
\text { differences across countries, since it is only in } \\
\text { Spain where the wage penalty of over-qualified } \\
\text { workers is negative and statistically significant. } \\
\text { Distinguishing between the three different types } \\
\text { of skill mismatch, NOBM,OWM, OBM (and taking } \\
\text { NOWM as reference group). NOBM,OWM } \\
\text { present a negative return in all countries. In Italy, } \\
\text { as well as in the other countries, the effect is } \\
\text { large: on average NOBM and OBM workers earn } \\
\text { about } 10,5 \text { percent less that properly matched } \\
\text { individuals. If instead the individual has the skills } \\
\text { required for the job (well matched) but is over- } \\
\text { qualified (OWM), a wage penalty is found only in } \\
\text { the cases of Spain and Italy. It should be noted } \\
\text { that even if significant the magnitude of the wage } \\
\text { penalty from being OWM is about one third of }\end{array}$ \\
\hline
\end{tabular}




\begin{tabular}{|c|c|}
\hline $\begin{array}{l}\text { Cainarca and } \\
\text { Sgobbi (2009) }\end{array}$ & $\begin{array}{l}\text { the data are taken from } \\
\text { the OAC-ISFOL survey on } \\
\text { employees in industrial } \\
\text { and service private secto } \\
\text { in } 2004\end{array}$ \\
\hline $\begin{array}{l}\text { Verhaest and } \\
\text { van der Velden (2010) }\end{array}$ & $\begin{array}{l}\text { International data set } \\
\text { REFLEX. Graduate in } \\
1999 / 2000 \text { in } 13 \\
\text { European countires } \\
\text { interviewee in } 2005\end{array}$ \\
\hline
\end{tabular}

Davia, McGuinness, O'Connell

(2010)

Ordine and Rose (2009)
The educational mismatch is defined as the correspondence between the education level possessed and the task performed. It has beeen measured comparing the education level and the self declared answer to the question: "Se qualcuno dovesse fare domanda per occupare la sua posizione,

che qualificazione scolastica dovrebbe possedere secondo lei? (En.Tr.: "If somebody should apply for your job, which kind of qualification would he need to hold?).

Overeducated are workers who feel for a present job more adequate a title lesser than a university degree (vertical mismatch). Earning indicator: not defined

the wage penalty in case of being badly matched (OBM) in all countries.

Thus, the authors conclude that in the five EU countries studied it is to a large extent skill mismatch what drives the wage penalty on wages and not over-qualification

In the sample overeducated are the $14,1 \%$ over total employees and undereducated are the

$17,1 \%$. The wage penalty is estimated by an ORU specification. As usual the years of

undereducation have a negative impact on wages $(-1,9)$ and the years of overeducation have a positive impact $(0,9)$ even if the premium is only a quater of that of the years of education.

The incidence of overeducation six months after graduation in Italy is $38,0 \%$ and five years after graduation is $19,3 \%$. On average, in the main OECD countries the incidence of overeducation is about $10 \%$ lower in the current job $(26,0 \%)$ compared to the first job $(15,6 \%)$. Italy has a high initial incidence of overeducation and, like the other countries in the same situation, has the largest drop after five years. Italy is also characterized by an overall low stability of match positions: this country combines a below average overeducation persistence with a relatively high probability to fall back in overeducation after an initial good match.

The average overeducation rate in Italy in 2004 2006 is $25,4 \%$ for males and $30,6 \%$ for females. Compared with the other countries the Italian rate is one of the highest and in particular the country exhibites relatively high levels of regional variation.

A wage equation is estimated in wich tha occurrence of overeducation is included as explanatory variable. Wage impact of overeducation is relevant (coefficient od OLS - 
graduated from Italian

higher education

$0,084)$ and significant, meaning that mismatched

graduates earn consistently less that their

matched peers and this may influence the

pattern of wage inequality within the group of

Source: Own elaboration. 